\title{
MUNICIPAL WASTE GENERATION AND COMPOSITION IN A TOURIST CITY - HOI AN, VIETNAM
}

\author{
Minh Giang HOANG ${ }^{1}$, Takeshi FUJIWARA ${ }^{2}$ and Song Toan PHAM PHU 3 \\ ${ }^{1} \mathrm{Ph}$. D. candidate, Dept. of Sound Material-Cycle Science, Okayama University \\ (3-1-1 Tsushima, Kita, Okayama 700-8530, Japan) \\ Email: pef84b6h@s.okayama-u.ac.jp \\ ${ }^{2}$ Professor, Dept. of Sound Material-Cycle Science, Okayama University \\ (3-1-1 Tsushima, Kita, Okayama 700-8530, Japan) \\ Email: takeshi@cc.okayama-u.ac.jp \\ ${ }^{3}$ Lecturer, Dept. of Environment, College of Technology - The University of Danang \\ (48 Cao Thang, Hai Chau, Danang, Vietnam) \\ E-mail: ppstoan@gmail.com
}

\begin{abstract}
A study to characterize municipal solid waste was carried out at various sources in Hoi An, a famous World Heritage City of Vietnam. The purpose of the research was to identify the generation rate and compositions of household waste from different types of areas of the city (rural, urban, and tourist quarters) as well as waste from tourism sources. The result will contribute to harmonized solid waste management for the city. Wastes from household, hotels, restaurants, and streets were collected daily in two weeks for generation and composition sampling. A stratified random sampling method was applied, and several statistical tools were carried out to analyze obtained data. As a result, the mean of household waste generation was $0.223 \mathrm{~kg}_{\text {capita }}{ }^{-1} \mathrm{day}^{-1}$. The average waste generation per capita in the urban region, which included the city center - ST1 $\left(0.203 \mathrm{~kg}\right.$ capita $^{-1}$ day $\left.^{-1}\right)$ and the urban areas - ST2 $\left(0.264 \mathrm{~kg} \mathrm{capita}^{-1}\right.$ day $\left.^{-1}\right)$, was almost double that of the countryside - ST3 $\left(0.12 \mathrm{~kg}\right.$ capita $^{-1}$ day $\left.^{-1}\right)$. The difference was statistically significant. Waste from tourism sources may have a great contribution in the total amount of waste generation since tourist services are important and active activities in the city. The results of the study showed that hotels generated about $0.6 \mathrm{~kg} \mathrm{room}^{-1} \mathrm{day}^{-1}$, one restaurant produced an average of $26.18 \mathrm{~kg} \mathrm{day}^{-1}$, and the mean of daily waste generation from tourist streets was $6.99 \mathrm{~kg}$ per $100 \mathrm{~m}$ per day. Degradable waste counted for more than half of municipal waste, and combustible waste (textile, leather, wood, diapers, etc.) had higher portions, which meant that biological and thermal treatment technologies could be potential options for the purpose of decreasing the amount of waste to landfill for the city.
\end{abstract}

Key Words : waste generation, municipal waste characterization, stratified random sampling, Hoi An city, Vietnam

\section{INTRODUCTION}

Hoi An City (HAC) is on the coast of the East Sea in the South Central Coast region of Vietnam, located in Quang Nam province and it is recognized as a World Heritage Site by UNESCO. The city has a natural land area of $6,171.25$ ha with a total population in 2013 of around 93,000 and population density of 1,508 people $\mathrm{km}^{-2}{ }^{1)}$. Hoi An is a small city, but it has been considered as the cultural center of Quang Nam, and is also the center of economic activities, especially tourism, in the province. The city is unique in Vietnam; it consists of various types of areas such as urban, suburban, and rural. The particularly famous touristic city (Hoi An ancient town), welcomes around 1.5 million tourists annually. Hence, the amount of municipal waste generated is great and increases gradually.

However, the municipal solid waste management system of the city has not been efficient, and the main problem in the city is a lack of appropriate and efficient treatment technologies. Currently, one composting plant with a capacity of 50 tonnes per day has been operating, but the composting product has not sold well. In 2013 and 2014 there were an accumulated amount of approximately 1.500 tonnes in stock. 
An opened dump landfill has led to huge adverse effects on the environment and public health. Hence, developing a sustainable municipal solid waste management system has become a necessity in the city.

It is clear that understanding the features of the waste stream is crucial for planning, design, and operation of a solid waste management (SWM) system $^{2), 3)}$. To develop a waste management system and choose appropriate treatment technologies, accurate and reliable data on the waste composition and generation are needed ${ }^{4)}$. However, physical, geographical, sociocultural, economic, and political factors may have influences on the composition and generation of municipal solid waste (MSW) ${ }^{5), 6)}$. Especially, the tourism industry may lead to significant influences to the environment with respect to resource consumption as well as pollution generation. One of the major impacts of tourism is the change in generation rate and composition of MSW as well as household waste. Some previous studies have reported the increase in MSW in the tourist areas resulting from the high number of tourists during the tourism season ${ }^{7), 8), 99,10)}$. Thus, waste composition and waste generation rates can be different in places influenced by, and in those not influenced by tourism. Study on variations of waste characterization among various regions in a tourist city may be beneficial in planning a sustainable system.

Study on waste has still lagged behind where it concerns waste arising from tourism operations due to the near absence of reliable data on MSW management related to this sector ${ }^{11)}$. In HAC, there are no studies on waste characterization in the city; a waste composition monitoring program has been carried out recently, but there has been no information on waste generation and waste composition from different sectors. The tourism industry in HAC now is considered one of the most dynamic industries and the greatest contributor to the development of the city; hence, a study on waste characterization of household and tourism sectors from various geographical areas would have a great contribution to a sustainable MSW management system planning.

The aim of this study was to provide detail waste generation and composition to evaluate differences in waste characterization among different types of urban areas as well as between household and tourism, the two biggest sources of municipal solid waste in the city. Results of the study would play a major role in developing a sustainable system such as choosing appropriate treatment options, designing collection system, or operating solid waste management system in the city. The authors also provided an advantageous framework including sampling procedures and appropriate statistical analysis, as a reference that is readily applicable to small-scale cities in Vietnam.

\section{METHODOLOGIES}

\section{(1) Research target areas and number of samples}

HAC comprises 13 administrative wards including an island ward that has its old waste management system. Thus, in this study, we focus on 12 neighbourhoods in the mainland. The City is a unique

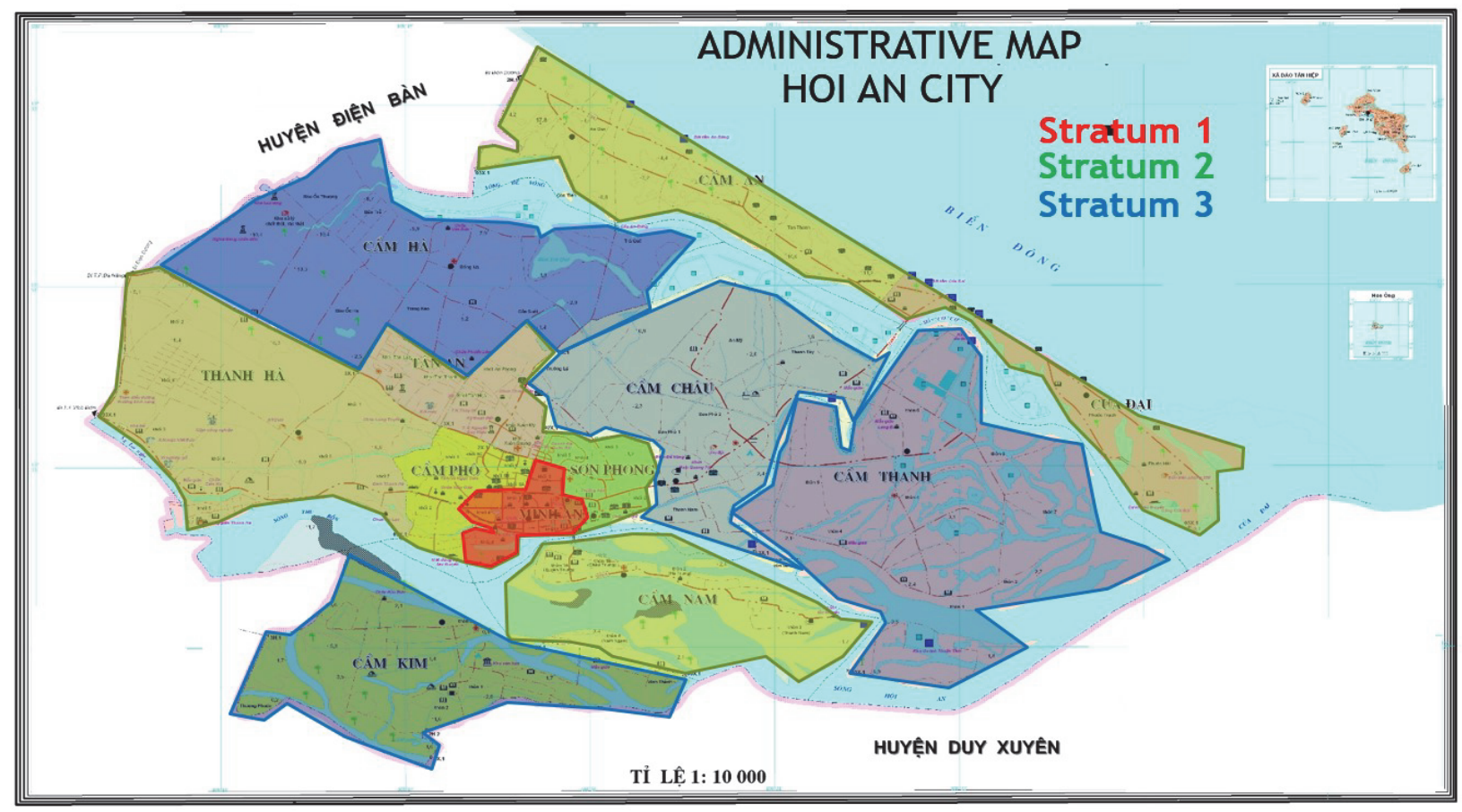

Fig.1 Target research areas. 
urban area in Vietnam, which consists of many types of areas including urban, rural places, and a famous tourist quarter (Hoi An ancient town). Therefore, in consideration of tourist factors affecting household waste generation, we divided the city into three strata (ST). ST1 is the Hoi An ancient town area including Minh An ward and part of Cam Pho Ward; ST2 comprises eight urban and suburban wards, and ST3 is a group of the other countryside wards (Tan Hiep island is excluded in this study). Figure 1 describes the three strata in this study; the ST1, ST2, and ST3 areas are represented by red, green, and blue, respectively.

The sampling strategy adopted in this study is stratified random sampling to reduce variations in household waste. We can apply the graph of Van der Broek and Kirov ${ }^{12)}$, which showed that the sampling ratio should be about 13 households per 1000 households to obtain a standard of error of $5 \%{ }^{13)}$. The number of statistical samples was estimated based on the data of households number in each ward from the Hoi An statistical yearbook $2013{ }^{1}$. Households participating in the survey program were randomly chosen from each stratum by $\mathrm{R}$ software from the lists of households in three strata, gathered from the Hoi An Center for Population and Family Planning.

To determine the waste characterization from various sources of the city, not only waste from households but also waste from tourist sources including hotels (HT), restaurants (RBC), and streets (STR) of tourist corners was chosen as targets of the study. The Hoi An Statistical Yearbook (2013) was used to identify and shortlist hotels and restaurants in the city, which would be chosen randomly as samples for waste quantity sampling. In Hoi An, there are several kinds of accommodations such as hotels, homestays, and guesthouses. Totally, nine types of accommodations for tourists including five hotels, three homestays and one guesthouse were selected randomly.

Table 1 Numbers of statistical samples adopted in the survey program.

\begin{tabular}{|llcc|}
\hline Code & Type of Sources & \multicolumn{2}{c|}{ Number of samples (n) } \\
\hline & & $\begin{array}{c}\text { Statistically } \\
\text { required }\end{array}$ & No. of samples \\
\hline ST1 & Stratum 1 & 36 & 50 \\
ST2 & Stratum 2 & 185 & 187 \\
ST3 & Stratum 3 & 64 & 84 \\
ST & Total HH & 285 & 321 \\
HT & Hotels & - & 9 \\
RBC & Restaurants & - & 6 \\
STR & Streets & - & 3 \\
\hline
\end{tabular}

For selecting restaurants, as suggested by independent local experts and authorities, restaurants in Hoi An were sorted into two types based on their locations: in the city center and along the beach. Thus, three of each type were randomly chosen for the survey.

Likewise, three walking streets in the Hoi An ancient quarter were selected to identify the amount of street waste generation and composition.

In this study, we randomly chose nine hotels, six restaurants, and three walking streets in tourist corners for samples collection. The number of households, hotels, restaurants, and streets in the survey is described in Table 1.

\section{(2) Sampling procedures}

The period of sampling was three weeks from August 2 to August 20, 2015. On the first week, we focused on training both students engaging in the sampling program and families selected as donors of household waste.

The actual sampling time was 14 days from August 7 to August 20. Every day, we collected wastes in the morning from households, hotels, restaurants and streets, then transported them to the waste treatment plant and separated them for composition analysis.

There were 25 students recruited from Danang College of Technology (DCT) in Vietnam. These students were trained and provided technical, safety guidelines, as well as personal protecting equipment such as rubber gloves, safety glasses, masks, and other equipment including plastic buckets, handkerchiefs, and record paper sheets.

In the first stage, all groups went to visit every single household invited to participate in the program and collected basic information (e.g., number of household members). As a result, a total of 321 households agreed to participate in the survey of waste sampling collection. Total households for each stratum were 50 for Stratum 1, 187 for Stratum 2, and 84 for Stratum 3.

Each family had a single identified code including two parts: the first part consisted of three digits presenting the name of the stratum (ST1, ST2, ST3) and the second part was the number of household by numerical order starting from 1 in each stratum. Every single household participating in the program was assigned a code marker in front of the door to avoid collection mistakes.

Waste sample collection was carried out from each selected household daily for two weeks from August 7th to August 20th. On the first day, not all waste samples were collected, while the second-day waste was collected completely but was later discarded to 
ensure that the waste to be analyzed had been generated in the last 24 hours. Every morning, collecting team members brought black plastic bags with the sample identification codes and transported the waste bags with household waste to the treatment plant to measure and record the weight.

Samples were separated few hours after being collected to minimize variations due to biological and chemical processes. On the first day of waste composition analysis, bags of household waste were randomly selected from those collected so that the total weight of the bags may be around $120 \mathrm{~kg}$. Thus, 70 waste bags from 70 households were selected randomly as samples for composition analysis including 13 from Stratum 1, 36 from Stratum 2, and 21 of Stratum 3. Samples of household waste that had been chosen on the first day would be kept as samples for the whole survey period.

On the other hand, bags of hotels and restaurants waste were selected randomly for composition analysis every day due to the huge amount of waste collected daily from these two sources. There was an average of around $105 \mathrm{~kg}$ of household waste and $145 \mathrm{~kg}$ of waste from restaurants, hotels, and streets separated daily. Waste samples were separated into ten primary components presented in Table 2. In this study, the effects of seasonal variations in waste characteristics were not investigated.

\section{(3) Statistical analysis}

Daily waste generation of household $j$ in strata $i$ is expressed as $w_{i, j}$. Waste generation rate and its average in strata $i$ are expressed in Eq (1) and Eq (2), respectively.

$$
\begin{gathered}
y_{i, j}=\frac{w_{i, j}}{h_{i, j}} \\
\bar{y}_{i}=\frac{1}{n_{i}} \sum_{j=1}^{n_{i}} y_{i, j}
\end{gathered}
$$

Where $h_{i, j}$ is the number of people of the household $j$ in stratum $i ; y_{i, j}$ is the daily waste generation per capita of household $j$ in stratum $i$; and $n_{i}$ is the number of sample households in stratum $i$.

In this study, we used geometric and standard deviation ${ }^{14)}$ for statistical measures to describe the mean of waste generation and percentages of waste components. For stratified random sampling, population mean of waste generation and composition was unbiasedly estimated by a weighted average of means of strata ${ }^{15), 16)}$, described by the following equation:

$$
\bar{y}_{s t}=\frac{1}{N} \sum_{i=1}^{L} n_{i} \bar{y}_{i}
$$

$\mathrm{N}, \mathrm{L}$ is the total number of households being surveyed and the number of strata, respectively.

Distribution of waste generation rate for each stratum is examined by using skewness and kurtosis. Skewness, expressed by Eq (4), is a measure of the asymmetry of the probability distribution of a real-valued random variable about its mean. The skewness value can be positive or negative, or even undefined. Kurtosis, expressed by Eq (5), is a measure of whether the data are heavy-tailed or light-tailed about to a normal distribution.

$$
\begin{gathered}
S_{i}=\frac{1}{N_{i}} \sum_{j=1}^{N_{i}} \frac{\left(y_{i, j}-\bar{y}_{i}\right)^{3}}{s_{i}{ }^{3}} \\
K_{i}=\frac{1}{N_{i}} \sum_{j=1}^{N_{i}} \frac{\left(y_{i, j}-\bar{y}_{i}\right)^{4}}{s_{i}{ }^{4}}
\end{gathered}
$$

\begin{tabular}{|c|c|}
\hline Primary components & Material \\
\hline Food waste & Degradable food remnants \\
\hline Yard waste & $\begin{array}{l}\text { Leaves, residual from gar- } \\
\text { dens, etc. }\end{array}$ \\
\hline Plastic & $\begin{array}{l}\text { Plastic bags, plastic bottles, } \\
\text { PET bottles, or plastic } \\
\text { packages, etc. }\end{array}$ \\
\hline Cardboard & $\begin{array}{l}\text { Cardboard, packing card- } \\
\text { board, cartons, milk and } \\
\text { juice package }\end{array}$ \\
\hline Paper & $\begin{array}{l}\text { Newsprint, magazines, } \\
\text { office paper, mixed paper, } \\
\text { tickets }\end{array}$ \\
\hline Metal & $\begin{array}{l}\text { Metal packaging, } \\
\text { non-packaging metal, } \\
\text { aluminum, iron, ferrous } \\
\text { metals, non-ferrous metals, } \\
\text { etc. }\end{array}$ \\
\hline Glass & $\begin{array}{l}\text { Glass bottles, all kinds of } \\
\text { glasses, etc. }\end{array}$ \\
\hline Combustible & $\begin{array}{l}\text { Textiles and leather, } \\
\text { healthcare textiles, carpeting } \\
\text { and mats, wood, bamboo, } \\
\text { rubber, napkins, sanitary } \\
\text { napkins, etc. }\end{array}$ \\
\hline Incombustible & $\begin{array}{l}\text { Inert materials and } \\
\text { non-combustible materials, } \\
\text { etc. }\end{array}$ \\
\hline Hazardous waste & $\begin{array}{l}\text { Battery, medical waste, } \\
\text { electrical devices, etc. }\end{array}$ \\
\hline
\end{tabular}

Where $s_{i}$ is a standard deviation of $y_{i, j}$.

Table 2 Categories of waste separation in samples. 
An analysis of variance (ANOVA) was carried out to analyze the significant differences in mean waste generation rate and waste compositions among sources and geographical areas. The total waste generation data and quantity of waste types were entered into Microsoft Excel 2013 to estimate means of waste generation per capita (for households), per room (for hotels), and 100 meters (for street) and percentage of waste components. Results were transformed by taking the logarithm of their original values ${ }^{17), 18)}$ to approximately close to a Normal distribution. Then, they were used as input data for $\mathrm{R}$ software (ver 3.2.0) where ANOVA was tested. To compare between strata, a post-hoc analysis was applied with Turkey's Honest Significance Difference method ${ }^{19), 20)}$ for pair comparisons.

During the time of survey program, waste collection from 30 households was not consistent. Therefore, we disregarded the ddata gathered from those families in the statistical analysis. As a consequence, data of 291 statistical samples for households were selected for analysis.

\section{RESULTS AND DISCUSSIONS}

\section{(1) Municipal waste generation}

\section{a) Household waste generation}

The waste generation rate of each household was calculated by dividing the amount of waste produced in a day with the number of family members ${ }^{21)}$.

Figure 2 shows the results of statistical estimates and the boxplot of waste generation rate; red dots present the mean of waste generation rate of each stratum, and small black dots are outlier observations.

Waste generation of ST1 and ST2 ranged from 0.00 to $0.70 \mathrm{~kg} \mathrm{capita}^{-1} \mathrm{day}^{-1}$, but ST3 took a lower range of $0.00-0.30 \mathrm{~kg}$ capita $^{-1}$ day $^{-1}$. These results showed that waste generation of households from rural areas (ST3) varied less than from urban areas (ST1 and ST2).

Figure 3 shows the density of waste generation rate of each stratum. It was found that each waste generation distribution of the three strata positively skewed like a normal bell-shaped curve distorted to the left. According to Tchobanoglous et al. ${ }^{14)}$, some degree of positive skewness is common in solid waste generation data. The ST3's distribution peaked because the coefficient of kurtosis was higher than the coefficient of kurtosis of the normal distribution, which was equal to $3^{14), 16), 22 \text { ). }}$

Previous studies used mean estimates and standard deviation (SD) ${ }^{16), 23)-26)}$ to describe the confidence interval of waste generation rate by tolerating the
Table 3 Means of waste generation and 95\% confident interval.

\begin{tabular}{|c|c|c|c|}
\hline \multirow[t]{2}{*}{ Stratum } & \multicolumn{3}{|c|}{$\begin{array}{l}\text { Waste generation rate }\left(\mathrm{kg} \mathrm{capita}^{-1}\right. \\
\left.\text { day }^{-1}\right)\end{array}$} \\
\hline & Mean & Upper limit & Lower limit \\
\hline ST1 & 0.203 & 0.046 & 0.900 \\
\hline ST2 & 0.264 & 0.085 & 0.823 \\
\hline ST3 & 0.120 & 0.024 & 0.604 \\
\hline
\end{tabular}

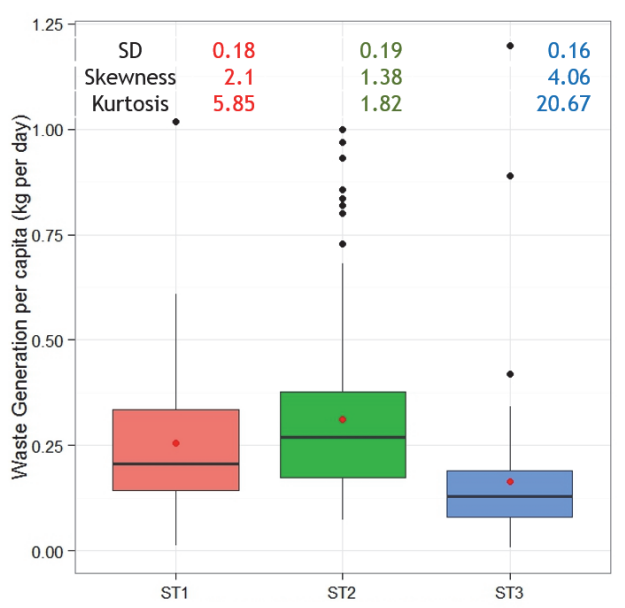

Fig.2 Boxplot of waste generation rate.

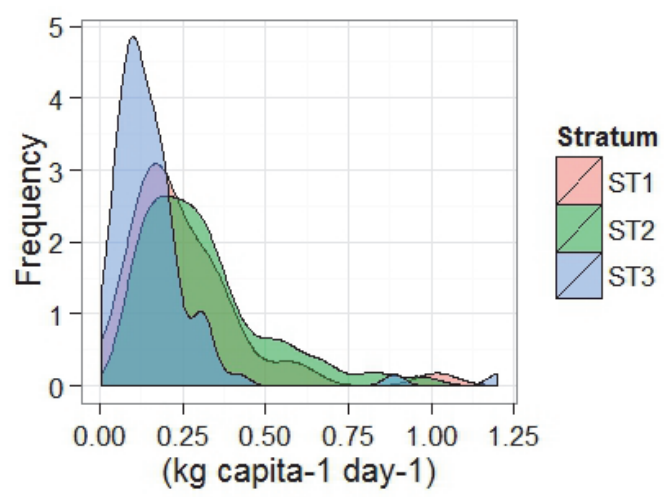

Fig.3 Density of waste generation rate.

small amount of skewness to have Normal distribution ${ }^{22}$. However, in this study we used geometric mean and standard deviation for statistical estimates of waste generation rate ${ }^{14)}$. The geometric mean of waste generation rate and $95 \%$ confidence interval are shown in Table 3. A person living in the countryside (ST3) generated half the amount of waste produced by a person living in the urban area.

Among different waste generation studies at household level in Vietnam, the rate was estimated at $0.285 \mathrm{~kg} \mathrm{capita}^{-1}$ day $^{-1}$ in Can Tho City ${ }^{24)}$ and 0.6 in Ho Chi My City, as reported by Tran et al. ${ }^{27)}$. Both cities mentioned above are bigger and more devel- 
Table 4 Results of variance analysis.

\begin{tabular}{|lccccc|}
\hline Source & DOF $^{1}$ & SOS $^{2}$ & MS $^{3}$ & $\mathrm{~F}^{4}$ & $\mathrm{P}^{5}$ \\
\hline $\begin{array}{l}\text { Between } \\
\text { Strata }\end{array}$ & 2 & 34.7 & 17.35 & 37.5 & $3.4 .10^{-15}$ \\
$\begin{array}{l}\text { Within } \\
\text { Strata }\end{array}$ & 288 & 133.3 & 0.46 & & \\
\hline $\begin{array}{l}{ }^{1} \text { Degree of freedom; }{ }^{2} \text { Sum of square; } \\
{ }^{3} \text { F-value; }\end{array}{ }^{5}$ Pevalue square; \\
\hline
\end{tabular}

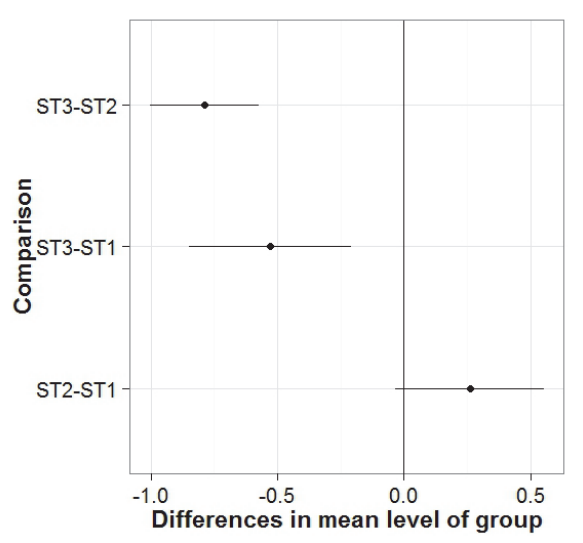

Fig.4 95\% family-wise confidence level.
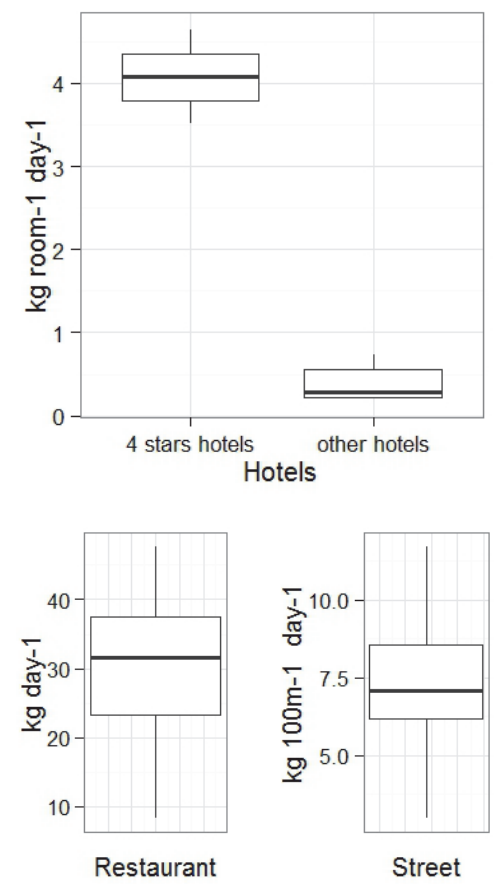

Fig.5 Boxplot of waste generation from tourism sector.

oped than Hoi An. Thanh et al. ${ }^{24)}$ sampled from 100 households for both rainy and dry seasons then estimated the mean of two results. Tran et al. ${ }^{27)}$ meanwhile, combined the amount waste after household separation to estimate the daily waste generation per household. This study assumed the average number of a family member was four to calculate waste generation per capita. Results of this study showed that the household waste generation rate in Hoi An was slightly lower compared to those in Can Tho city and Ho Chi Minh City. The overall mean of household waste generation rate was 0.223 $\mathrm{kg}$ capita $^{-1}$ day $^{-1}$ with average varying between 0.207 and $0.240 \mathrm{~kg}$ capita $^{-1}$ day $^{-1}$. Thus, total household waste generation of the city was estimated at 20.75 tonnes per day.

According to the data of Hoi An Public Works Service Co. Ltd. (HAPWC) report regarding the daily waste amount, we estimated the average amount of city municipal waste transported to a treatment facility, which was about 70.13 tonnes day $^{-1}$. Therefore, daily household waste generation accounted for approximately $30 \%$ of total municipal waste in Hoi An City. The results of ANOVA (Table 4) indicated that there were differences between waste generation rates among the three Strata (signals were much higher than noises), and the differences were statistically significant ( $p$-value $<0.05$ ).

Figure 4 presents the post-hoc analysis results. Horizontal lines indicate the $95 \%$ confidence interval of differences of average waste generation between strata. If the $95 \%$ confidence interval line is not crossing the zero line, it meant waste generation rate was significantly different between two strata. The result showed that waste generation rate in ST3 was significantly different from those in ST1 and ST2. Thus, the waste generation rate from urban areas was double that from rural places, and the difference was statistically significant. The result of the study would be useful in the prediction of waste generation for a waste management planning program.

Tourist area (ST1) produced less waste per capita than did the urban and suburban areas (ST2) as a result of this survey. Family business and involvement in tourism services of people living in the center (ST1) had significant impact on family lifestyle, such as reduced time at home, eating outside, or less time spent together with family members could be a reason for less waste produced. However, this difference was not statistically significant as shown in Figure 4.

\section{b) Waste generation from tourism sectors}

The estimated average waste generation from hotels was $1.22 \mathrm{~kg} \mathrm{room}^{-1}$ day $^{-1}$. However, there was a significant difference between hotels with large capacity (four stars hotels in this study) and hotels with small capacity (three stars and two stars hotels and homestays.

As can be seen from Figure 5, high standards hotels generated about $4 \mathrm{~kg} \mathrm{room}{ }^{-1}$ day $^{-1}$; meanwhile, three stars and lower standard hotels produced about $0.35 \mathrm{~kg} \mathrm{room}^{-1} \mathrm{day}^{-1}$. Chan and $\mathrm{Lam}^{28)}$ reported that mean of waste generation from a room in midscale hotels (which included three and four stars hotels) in 
Hong Kong was $2.76 \mathrm{~kg} \mathrm{room}^{-1}$ day $^{-1}$ and from hotel restaurants were $0.75 \mathrm{~kg}$ per meal cover in 1996. The hotel waste generation rate tended to decrease as a result of Chan and Lam ${ }^{28)}$ estimated model. However, waste from guest rooms and restaurants of hotels were studied separately in the research mentioned above.

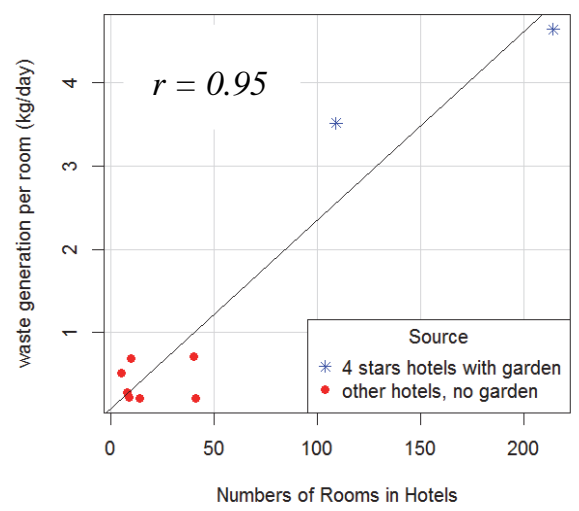

Fig.6 Correlation of mean of waste generation and number of hotel room.

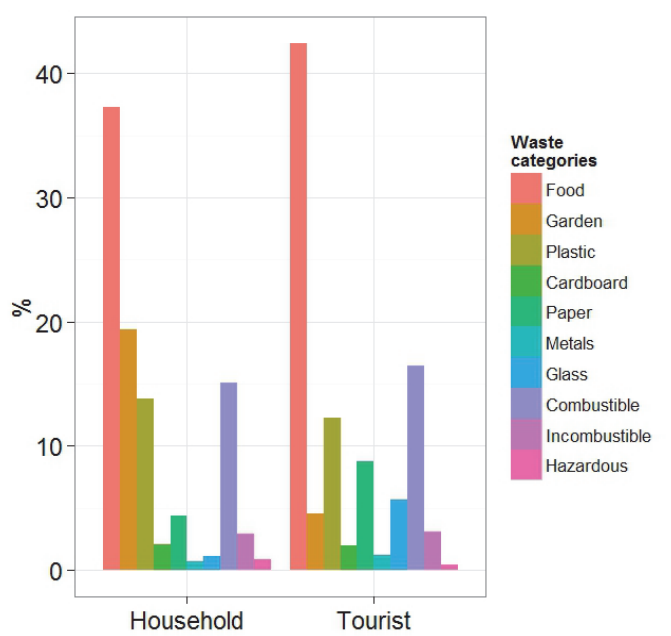

Fig.7 Waste composition of household and tourism sector.

Table 5 Waste composition of different sources regarding tourism waste.

\begin{tabular}{|lccc|}
\hline $\begin{array}{l}\text { Waste } \\
\text { Compositions } \\
(\%)\end{array}$ & $\begin{array}{c}\text { Hotel } \\
\text { waste }\end{array}$ & $\begin{array}{c}\text { Restaurant } \\
\text { waste }\end{array}$ & $\begin{array}{c}\text { Street } \\
\text { waste }\end{array}$ \\
\hline Food & 49.0 & 39.5 & 39.4 \\
Garden & 7.2 & 6.4 & 1.4 \\
Plastic & 16.4 & 8.4 & 13.8 \\
Cardboard & 3.2 & 1.9 & 1.0 \\
Paper & 9.7 & 9.6 & 6.7 \\
Metals & 0.7 & 2.2 & 0.4 \\
Glass & 3.4 & 9.4 & 4.5 \\
Combustible & 8.6 & 15.3 & 31.8 \\
Incombustible & 0.7 & 7.0 & 0.8 \\
Hazardous & 1.0 & 0.3 & 0.2 \\
\hline
\end{tabular}

The results of this study were significantly lower than those of Trung and Kumar ${ }^{29)}$, who estimated waste generation rate by a questionnaire survey of 50 hotels in Vietnam. Trung and Kumar ${ }^{29)}$ reported that two and three stars hotels generated $0.7-5.6$ and 8.2 $-17.9 \mathrm{~kg}$ guest $^{-1}$ day $^{-1}$, respectively while four stars hotels produced $13.5-32.3 \mathrm{~kg}$ guest ${ }^{-1}$ day $^{-1}$. Byer et al., ${ }^{30)}$ meanwhile, indicated that the waste generation rate of two, three, and four stars hotels appeared identical from 0.4-0.5 kg guest ${ }^{-1}$ day $^{-1}$.

Figure 6 describes the correlation between the number of hotel rooms and waste generation rate. The results of correlation analysis showed that the coefficient of correlation (r) was 0.95 , and it was statistically significant $(p<0.05)$. The coefficient of determination was 0.91 , which meant that $91 \%$ variations in waste generation rate could be explained by the number of hotel rooms.

The average waste generation measured was 28.85 $\mathrm{kg}$ day $^{-1}$ from restaurants and $7.35 \mathrm{~kg} 100 \mathrm{~m}^{-1}$ day $^{-1}$ from street litter.

On $95 \%$ Confidence interval, the means of waste generation rate from tourism sources were estimated as follows:

- Hotels: $0.6 \mathrm{~kg} \mathrm{room}^{-1} \mathrm{day}^{-1}$, range from 0.05 to 6.07 .

- Restaurants: $26.18 \mathrm{~kg} \mathrm{day}^{-1}$, range from 7.68 to 89.30 .

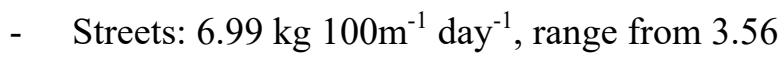
to 13.67 .

\section{(2) Municipal waste composition}

The composition of household waste was made up of $38 \%$ food waste, $19 \%$ yard waste, $14 \%$ plastic, $15 \%$ combustible waste, and others including cardboards, paper, metals, glass, incombustible waste, and hazardous waste constituted less than 5\% (Figure 7). The major components of household waste in Hoi An were food waste and yard trimmings (19\%), which together constituted $57 \%$ of the total household waste. Metal and hazardous material were the smallest contributors to household waste stream.

The waste stream of tourism sources (including hotels, restaurants, and streets) was different compared to that of the household waste stream (Fig.7 and Table 5). The portion of food waste of tourism was slightly higher $(42 \%)$ but the garden waste was significantly lower $(4.5 \%)$ than that of household. Glass materials released from the tourism industry were far greater than those from households. It was understandable because tourism service activities produced huge amounts of glass, especially beverage bottles. Both household and tourism wastes had high portions of plastic and combustible materials (as explained in Table 2). 
Table 5 shows the percentage of waste compositions from hotels, restaurants, and streets separately. All three sources of waste had a high portion of food waste. Activities of restaurants on streets and leftovers discharged by walking tourists could explain the high amount of food waste in street litter bins. Naturally, we found higher amount of glass waste such as discarded beer and wine bottles during the sampling period.

Chan and Lam ${ }^{28)}$ declared that plastic toiletries constituted the highest portion (above 50\%) of waste from hotel guest rooms. Byer et al., ${ }^{30)}$ indicated that compostable material (including food waste and yard waste) formed the largest portion of the hotel waste stream, accounting for approximately $60 \%-70 \%$. It was slightly higher than the compostable material portion in this study.

Figure 8 provides the waste compositions of households from the individual stratum. In comparison between strata, the portion of food waste in ST1 was higher (at about $43.3 \%$ on average) but less garden waste $(7.54 \%)$ than the other two strata. ST2 and ST3 had nearly similar percentages of food and garden waste of around $35 \%$ and $19 \%$, respectively. The percentages for most of the categories of ST2, ST3 (Fig.8), and total household (Fig.7) were apparently identical. Meanwhile, ST1 (Fig.8) and Tourist (Fig.7) waste were similar in shape to a higher percentage of food and glass waste, though a lower proportion of garden waste. Thus, the household waste characterization was different between an area affected by tourism (ST1), and two areas less affected by tourism activities (ST2 and ST3). However, the results from ANOVA indicated that differences in waste composition were not statistically significant $(\mathrm{p}<0.05)$.

Figure 9 shows the municipal waste composition of the city, in which the largest proportion was food wastes $(42 \%)$ and hazardous waste was the least portion (less than 1\%). Garden waste, plastic, and combustible materials were significant contributors ranging from $12 \%$ to $16 \%$. Other components were less than $10 \%$ of total waste.

Similar values of total degradable waste were reported by Hoi An Public Works Service Co. Ltd. (HAPWC) in September 2015. However, the report indicated that the percentage of yard waste was much higher than that of food waste.

Studies for solid waste composition analysis implemented various approaches without common international standards. Therefore, it was difficult to compare results of different sampling and sorting methodologies ${ }^{4), 31)}$. The portion of biodegradable waste (food waste and garden waste) was slightly lower than those in developing cities such as Beijing,
China $(69.3 \%)^{26)}$, Cape Haitian, Haiti $(66.6 \%)^{25)}$, Kathmandu, Nepal (71\%), Can Tho, Vietnam $(80 \%)^{24)}$ and Da Nang City, Vietnam $(68,5 \%)^{32)}$. However, recyclable waste components such as plastics, cardboards, papers, and metals were approximately alike compared to the above studies. The difference could be caused by different lifestyles and dietary habits as well as differences in the effects of tourism industry between Hoi An and other cities. Combustible waste, on the other hand, was not investigated in the studies mentioned above, but it was one of the major components in municipal waste in HAC.

Significant quantities of food waste, garden waste, and combustible waste proved that we might consider introducing biological and thermal treatment technologies as potential treatment options for municipal solid waste. However, the composting plant in Hoi An currently has been operating unsuccessfully like most of the other composting plants in Vietnam. Failure in composting technologies are caused by various factors such as inappropriate pre-treatment techniques, not enough attention to the biological process requirements; poor quality of the fertilizers,

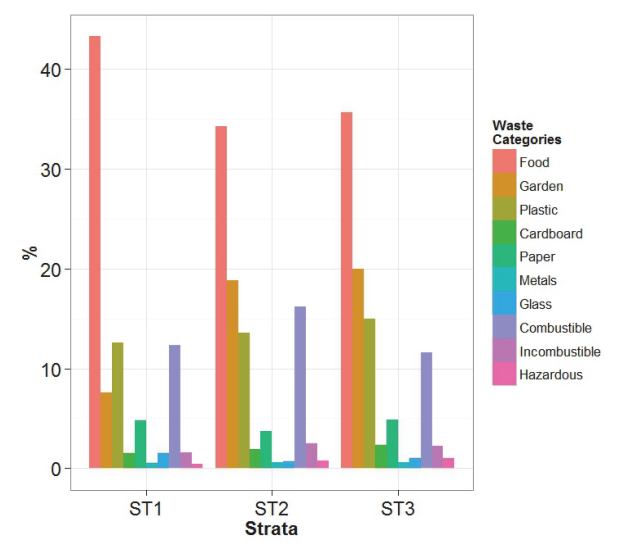

Fig.8 Household waste compositions of thee strata.

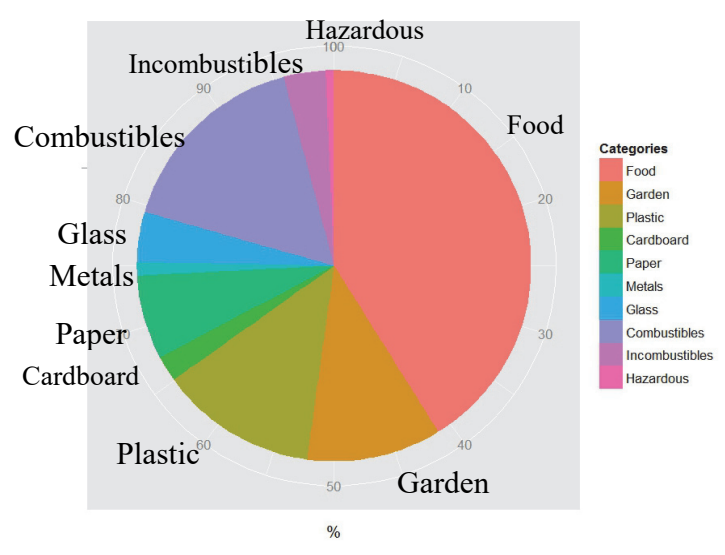

Fig.9 Municipal waste compositions. 
and poor marketing experiences ${ }^{33)}$. Centralized composting plant with high capacity might be improper for the Hoi An condition due to lack of management skills, operating funds, and low technology application. Thus, decentralized biological treatment (small-scale plants, home composting) seem advisable to apply in these conditions, especially with households in rural and suburban areas that have gardens and engaged in agriculture. However, socio and economic incentives should be studied to encourage decentralized organic waste treatment.

Thermal treatment, on the other hand, has been considered one of the best technologies in term of energy recovery and reducing waste to landfill in MSW management ${ }^{34)}$. Waste incineration has been getting more attraction from the city authorities. The high portion of combustible waste in Hoi An indicated that incineration technology might be a potential option for the city waste treatment system. Nevertheless, the total amount of waste produced is about 70 tonnes per day, and the capacity of waste incineration will be not high. Thus, a study on the characteristics of waste such as heating value, moisture content, and chemical elements $(\mathrm{C}, \mathrm{N}, \mathrm{H})$ is required to determine the potential of incineration. A cost-benefit study for incineration without energy recovery facilities also should be carried out.

Recyclable waste (plastic, cardboard, paper, and metal) accounted for a large percentage of around $20 \%$ giving a good chance for material recovery. However, informal recycling activities for plastics, cardboard, and some other materials by organized waste pickers at treatment plants are currently adequate. Also, current recycling activities employ residents living nearby Hoi An waste treatment plant and are supported by local people. A material recovery program, therefore, may not be warranted for now because of social and technological constraints, but should be taken into account in the future.

\section{CONCLUSIONS}

Detailed survey and analysis of waste generation and composition in a tourism city, Hoi An, Vietnam, were conducted to evaluate differences among types of urban as well as between household waste and tourism waste. The findings are as follows:

Daily per capita household waste generation was $0.223 \mathrm{~kg}$ capita $^{-1} \mathrm{day}^{-1}$. Total household waste generation rate in Hoi An City was 20.75 tonnes per day, which accounted for about $30 \%$ of total municipal waste generation.

People living in rural areas generated about half of the amount of daily waste compared to people living in urban areas. On the other hand, residents in the urban areas highly affected by tourism activities produced less waste than in areas not affected by such activities.

Hotels generated about $0.6 \mathrm{~kg} \mathrm{room}^{-1} \mathrm{day}^{-1}$ and one restaurant in HAC produced an average of $26.18 \mathrm{~kg}$ day $^{-1}$. The mean of waste generation from tourist streets was $6.99 \mathrm{~kg} 100 \mathrm{~m}^{-1}$ day $^{-1}$. The study found that hotels with garden and higher standard (four stars) created more waste than lower-standard hotels. Regarding the correlations between the waste generation rate and the number of hotel rooms, the result indicated a statistically significant correlation between the number of rooms and total waste generation of hotels. The coefficient of correlation (r) was 0.95 , and the coefficient of determination was 0.91 .

The municipal waste composition of the city had food waste as the largest proportion (42\%) and hazardous waste as the smallest contributor (less than $1 \%$ ). Total biodegradable waste (food and yard trimmings) was approximately 53\%. Combustible waste was the second significant component of about $16 \%$ while other recyclable contributed about $20 \%$ of the municipal waste composition.

Waste composition in the city center was affected by tourism services because it was different from other areas and likely alike with the waste composition of the tourism sector in food, garden, and some other components.

Results from this study suggested a methodology of waste characterization survey based on characteristics of urban areas. The results and methodology are accepted to be informative for authorities, decision makers, stakeholders, and planners in developing a waste management plan.

Regarding the potential treatment technologies, we suggested that biological and thermal treatment technology should be considered as highly potential options for municipal solid waste to reduce waste to landfill. A recyclable material program should be developed in the future toward sustainable waste management.

ACKNOWLEDGMENTS: We acknowledge with gratitude the efforts of students and field assistants from Hoi An Public Works Ltd.Co. We are also grateful to the Hoi An solid waste treatment plant and College of Technology - The University of Danang for the use of their facilities. The financial support from the Research Grant for Encouragement of Students of Okayama University is greatly acknowledged. 


\section{REFERENCES}

1) HASD: Statistical Yearbook - Hoi An City, Hoi An Statistical Department, Viet Nam, 2013.

2) Chang, N.-B. and Pires, A.: Technology matrix for solid waste management, In: Sustainable Solid Waste Management, John Wiley \& Sons, pp. 19-97, 2015.

3) Abu Qdais, H. A., Hamoda, M. F. and Newham, J.: Analysis of residential solid waste at generation sites, Waste Management \& Research, Vol. 15, No. 4, pp. 395-405, 1997.

4) Edjabou, M. E., Jensen, M. B., Götze, R., Pivnenko, K., Petersen, C., Scheutz, C. and Astrup, T. F.: Municipal solid waste composition: Sampling methodology, statistical analyses, and case study evaluation, Waste Management, Vol. 36, pp. 12-23, 2015.

5) Gallardo, A., Carlos, M., Peris, M. and Colomer, F. J.: Methodology to design a municipal solid waste generation and composition map: A case study, Waste Management, Vol. 34, No. 11, pp. 1920-1931, 2014

6) Gidarakos, E., Havas, G. and Ntzamilis, P.: Municipal solid waste composition determination supporting the integrated solid waste management system in the island of Crete, Waste Management, Vol. 26, No. 6, pp. 668-679, 2006.

7) Teh, L. and Cabanban, A. S.: Planning for sustainable tourism in southern Pulau Banggi: An assessment of biophysical conditions and their implications for future tourism development, Journal of Environmental Management, Vol. 85, No. 4, pp. 999-1008, 2007.

8) Espinosa Lloréns, M. d. C., Torres, M. L., Álvarez, H., Arrechea, A. P., García, J. A., Aguirre, S. D. and Fernández, A.: Characterization of municipal solid waste from the main landfills of Havana City, Waste Management, Vol. 28, No. 10, pp. 2013-2021, 2008.

9) Denafas, G., Ruzgas, T., Martuzevičius, D., Shmarin, S., Hoffmann, M., Mykhaylenko, V., Ogorodnik, S., Romanov, M., Neguliaeva, E., Chusov, A., Turkadze, T., Bochoidze, I. and Ludwig, C.: Seasonal variation of municipal solid waste generation and composition in four East European cities, Resources, Conservation and Recycling, Vol. 89, pp. 22-30, 2014.

10) Shamshiry, E., Nadi, B., Bin Mokhtar, M., Komoo, I., Saadiah Hashim, H. and Yahaya, N.: Integrated models for solid waste management in tourism regions: Langkawi Island, Malaysia, Journal of Environmental and Public Health, Vol. 2011, 2011.

11) Ezeah, C., Fazakerley, J. and Byrne, T.: Tourism waste management in the European Union: Lessons learned from four popular EU tourist destinations, American Journal of Climate Change, Vol. 4, No. 05, pp. 431, 2015.

12) Van der Broek, E. and Kirov, N.: The characterization of municipal solid wastes, Proc. Australian Waste Disposal Conference Sydney, 1971.

13) Nordtest: Solid waste, municipal: Sampling and characterisation (NT ENVIR 001), Nordtest method, Finland, 1995.

14) Tchobanoglous, G., Theisen, H. and Vigil, S.: Integrated Solid Waste Management: Engineering Principles and Management Issues, McGraw-Hill, 1993.

15) Scheaffer, R., Mendenhall III, W., Ott, R. and Gerow, K.: Elementary Survey Sampling, Cengage Learning, 2011.

16) Bolaane, B. and Ali, M.: Sampling household waste at source: Lessons learnt in Gaborone, Waste Management \& Research, Vol. 22, No. 3, pp. 142-148, 2004.

17) Bernache-Pérez, G., Sánchez-Colón, S., Garmendia, A. M., Dávila-Villarreal, A. and Sánchez-Salazar, M. E.: Solid waste characterisation study in the Guadalajara Metropolitan Zone, Mexico, Waste Management \& Research, Vol.
19, No. 5, pp. 413-424, 2001.

18) Brown, L. C. and Mac Berthouex, P.: Statistics for Environmental Engineers, CRC Press, 2002.

19) Tuấn, N. V.: Phân tích dữ liệu với R. T. P Hồ Chí Minh: Nhà xuất bản Tổng Họp Thành phố Hồ Chí Minh, 520, 2014.

20) Longnecker, M. and Ott, R.: An Introduction to Statistical Methods and Data Analysis, ISBN-13, 854576151, 2001.

21) Dangi, M. B., Pretz, C. R., Urynowicz, M. A., Gerow, K. G. and Reddy, J. M.: Municipal solid waste generation in Kathmandu, Nepal, Journal of Environmental Management, Vol. 92, No. 1, pp. 240-249, 2011.

22) Dangi, M. B., Urynowicz, M. A., Gerow, K. G. and Thapa, R. B.: Use of stratified cluster sampling for efficient estimation of solid waste generation at household level, Waste Management \& Research, Vol. 26, No. 6, pp. 493-499, 2008.

23) Gomez, G., Meneses, M., Ballinas, L. and Castells, F.: Characterization of urban solid waste in Chihuahua, Mexico, Waste Management, Vol. 28, No. 12, pp. 2465-2471, 2008.

24) Thanh, N. P., Matsui, Y. and Fujiwara, T.: Household solid waste generation and characteristics in Mekong Delta City, Vietnam, Journal of Environmental Management, Vol. 91, No. 11, pp. 2307-2321, 2010.

25) Philippe, F. and Culot, M.: Household solid waste generation and characteristics in Cape Haitian City, Republic of Haiti, Resources, Conservation and Recycling, Vol. 54, No. 2, pp. 73-78, 2009.

26) Qu, X.-y., Li, Z.-s., Xie, X.-y., Sui, Y.-m., Yang, L. and Chen, Y.: Survey of composition and generation rate of household wastes in Beijing, China, Waste Management, Vol. 29, No. 10, pp. 2618-2624, 2009.

27) Tran, D. T., Le, T. M. and Nguyen, V. T.: Composition and generation rate of household solid waste: Reuse and recycling ability, International Journal of Environmental Protection, Vol. 4, No. 6, pp. 73-81, 2014.

28) Chan, W. W. and Lam, J.: Environmental accounting of municipal solid waste originating from rooms and restaurants in the Hong Kong hotel industry, Journal of Hospitality \& Tourism Research, Vol. 25, No. 4, pp. 371-385, 2001.

29) Trung, D. N. and Kumar, S.: Resource use and waste management in Vietnam hotel industry, Journal of Cleaner Production, Vol. 13, No. 2, pp. 109-116, 2005.

30) Byer, P. H., Hoang, C. P., Nguyen, T. T. T., Chopra, S., Maclaren, V. and Haight, M.: Household, hotel and market waste audits for composting in Vietnam and Laos, Waste Management \& Research, Vol. 24, No. 5, pp. 465-472, 2006.

31) Dahlén, L. and Lagerkvist, A.: Methods for household waste composition studies, Waste Management, Vol. 28, No. 7, pp. 1100-1112, 2008.

32) MONRE: Báo cáo môi trường quốc gia 2011: Chất thải rắn (National Environment Report 2011: Solid Waste), Bộ Tài nguyên và Môi truòng: Hà Nội, Việt Nam, 2011.

33) Nguyen Thi, K. T.: Municipal solid waste management in Vietnam challenges and solutions, In: Municipal Solid Waste Management in Asia and the Pacific Islands, Springer, pp. 355-377, 2014.

34) Kathirvale, S., Muhd Yunus, M. N., Sopian, K. and Samsuddin, A. H.: Energy potential from municipal solid waste in Malaysia, Renewable Energy, Vol. 29, No. 4, pp. 559-567, 2004.

(Received April 12, 2016) 